Article

\title{
Gravity-Driven Adaptive Evolution of an Industrial Brewer's Yeast Strain towards a Snowflake Phenotype in a 3D-Printed Mini Tower Fermentor
}

\author{
Andreas Conjaerts and Ronnie G. Willaert * \\ Alliance Research Group VUB-UGent NanoMicrobiology (NAMI), IJRG VUB-EPFL, \\ BioNanotechnology \& NanoMedicine (NANO), Structural Biology Brussels (SBB), \\ Vrije Universiteit Brussel, Brussels 1050, Belgium; Andreas.Conjaerts@vub.ac.be \\ * Correspondence: Ronnie.Willaert@vub.ac.be; Tel.: +32-2-629-1846
}

Academic Editors: Maurizio Ciani and Badal C. Saha

Received: 29 August 2016; Accepted: 3 January 2017; Published: 5 January 2017

\begin{abstract}
We designed a mini tower fermentor that is suitable to perform adaptive laboratory evolution (ALE) with gravity imposed as selective pressure, and suitable to evolve a weak flocculating industrial brewers' strain towards a strain with a more extended aggregation phenotype. This phenotype is of particular interest in the brewing industry, since it simplifies yeast removal at the end of the fermentation, and many industrial strains are still not sufficiently flocculent. The flow of particles (yeast cells and flocs) was simulated, and the theoretical retainment advantage of aggregating cells over single cells in the tower fermentor was demonstrated. A desktop stereolithography (SLA) printer was used to construct the mini reactor from transparent methacrylic acid esters resin. The printed structures were biocompatible for yeast growth, and could be sterilised by autoclaving. The flexibility of 3D printing allowed the design to be optimized quickly. During the ALE experiment, yeast flocs were observed within two weeks after the start of the continuous cultivation. The flocs showed a "snowflake" morphology, and were not the result of flocculin interactions, but probably the result of (a) mutation(s) in gene(s) that are involved in the mother/daughter separation process.
\end{abstract}

Keywords: 3D printing; mini tower fermentor; Saccharomyces cerevisiae; industrial brewer's yeast; adaptive laboratory evolution (ALE); snowflake phenotype

\section{Introduction}

The use of evolutionary methods is a more "natural" approach to enhance the attributes of microorganisms, in contrast to genetic modification which has so far precluded its commercial use due to the low consumer tolerance for genetically modified organisms [1,2]. Evolutionary methods can be applied even before the genetic elements and their global interactions required for optimal performance by an organism are understood. Recently, artificial laboratory selection of microbial cells has been introduced to generate potentially robust and optimised microbial production systems $[3,4]$. Adaptive laboratory evolution (ALE) strategies allow for the metabolic engineering of microorganisms by combining genetic variation with the selection of beneficial mutations in an unbiased fashion [5]. A number of investigations have demonstrated the feasibility of directing evolution in natural Saccharomyces pastorianus hybrid stains in order to create variant strains with improved functional properties [6]. Such investigations have focused on adaptation to very high-gravity brewing conditions [7-9], associated stresses (such as osmotic stress and ethanol toxicity) [10,11], or the modification of the production of flavour compounds [12]. ALE has also been utilised to enhance the fermentation rate of $S$. cerevisiae with decreased formation of acetate and greater production of aroma compounds [13,14]. 
Continuous culture provides many benefits over classical batch-style cultivation to perform experimental evolution [15]. Steady-state cultures allow for precise control of growth rate and environment, and cultures can be propagated for weeks or months in these controlled environments, which is important for the study of experimental evolution. Continuous mini bioreactors have been successfully used as multiplexed chemostat arrays for adaptive evolution experiments with yeast cells $[15,16]$. The use of mini bioreactors has several advantages, such as reduced costs for media and labour, and the ability to perform a large number of fermentations in parallel [17-19].

Recently, three-dimensional (3D) printing has been used for medical applications [20], such as (1) medical models; (2) medical aids, orthoses, splints, and prostheses; (3) tools, instruments, and parts for medical devices; (4) inert implants; and (5) biomanufacturing [21-24]. Bioprocess applications include tissue engineering scaffolds and corresponding bioreactors [25]. 3D printing has recently been used to fabricate fullerene-type biocarriers for biofilm growth that can be used in bioreactors for wastewater treatment [26]. 3D printing technology shows great potential for the easy development of mini-scale bioreactors. Here, we report the use of 3D printing for the construction of a continuous mini tower fermentor.

The concept of 3D printing-also referred to as additive manufacturing, rapid prototyping, or solid-freeform fabrication (SFF)—was developed by Charles Hull in the early 1980's [27]. 3D printing is used for rapid prototyping of 3D models originally generated by a computer aided design (CAD) program. The 3D model is sliced into 2D horizontal cross sections, which are printed in consecutive layers. There are several well-established methods of 3D-printing, such as stereolithography (SLA), fused deposition modelling, selective laser sintering, multi jet fusion, and selective laser melting. SLA became the first commercialised 3D-printing technique (invented by Charles Hull in 1983), and remains one of the most powerful and versatile of all SFF techniques [28]. SLA works by exposing a layer of photosensitive liquid resin to a UV-laser beam so that the resin hardens and becomes solid. Once the laser has swept a layer of resin in the desired pattern and it begins to harden, the model-building platform in the liquid tank of the printer steps down the thickness of a single layer, and the laser begins to form the next layer. SLA is capable of printing at high resolutions (up to $25 \mu \mathrm{m}$ ) and relatively high production rates $(1.5 \mathrm{~cm} / \mathrm{h})$.

In this contribution, we designed a continuous mini bioreactor that is suitable to perform ALE of a weak flocculating industrial brewers' strain towards a strain with a more extended aggregation (flocculation) phenotype. Yeast strains that aggregate or flocculate are of particular interest to the brewer, since it simplifies yeast removal at the end of the primary fermentation [29]. Since many industrial brewing strains still show no adequate flocculation, we applied ALE as a non-genetic engineering method. The design of the fermentor was based on a continuous mini tower fermentor; i.e., the continuous A.P.V. tower fermentor that was used in the 1960 s to produce beer on an industrial scale in a British brewery [30,31]. In this type of fermentor, gravity is the selective pressure to enhance the aggregation phenotype during evolution. We demonstrate that SLA 3D printing can be used to construct the mini tower fermentor, and that the design is suitable to obtain a yeast cell aggregation ("snowflake") phenotype by performing ALE.

\section{Materials and Methods}

\subsection{Yeast Strains and Media}

An industrial S. cerevisiae brewer's strain was used; i.e., CMBSVM22 from the yeast collection of prof. em. Freddy Delvaux (Centre for Malting and Brewing Science (CMBS), Katholieke Universiteit Leuven, Leuven Belgium; Biercentrum Delvaux, Beekstraat 20, 3040 Neerijse, Belgium) [32]. The haploid S. cerevisiae BY4742 strain [33] was used for the biocompatibility assay, and the flocculent BY4742 [FLO1] strain [34] for the preliminary experiments during experimental design optimisation. These strains were precultured in YPD (Yeast extract-Peptone-Dextrose) medium ( $1 \% \mathrm{~m} / v$ yeast extract, $2 \% \mathrm{~m} / v$ meat peptone, $4 \% \mathrm{~m} / v$ D-glucose) overnight at $30{ }^{\circ} \mathrm{C}$. Growth medium (100 g/L D-glucose, 
$4 \mathrm{~g} / \mathrm{L}\left(\mathrm{NH}_{4}\right) \mathrm{SO}_{4}, 1.5 \mathrm{~g} / \mathrm{L} \mathrm{KH}_{2} \mathrm{PO}_{4}, 1 \mathrm{~g} / \mathrm{L} \mathrm{MgSO} 4.7 \mathrm{H}_{2} \mathrm{O}$, and $5 \mathrm{~g} / \mathrm{L}$ yeast extract) was used for the continuous adaptive evolution experiment in the mini tower bioreactor.

WL (Wallerstein Laboratory) nutrient agar was used to differentiate between colonies by morphology variations $[35,36]$. The medium contained $7.5 \mathrm{~g}$ WL nutrient agar per $100 \mathrm{~mL}$ deionized water. The cell suspensions were diluted to $10 \times 10^{6}$ cells $/ \mathrm{mL}$ with sterile deionized water. Four droplets of $1 \mu \mathrm{L}$ of the diluted suspension were spotted on each plate.

\subsection{Determination of Cell Concentration and Growth Rate}

The cell concentration was determined by cell dry mass (CDM) and optical density (OD) measurements. For CDM measurements, a sampled cell suspension of $3 \mathrm{~mL}$ was filtered with a $0.45-\mu \mathrm{m}$ filter (Type HVLP, Millipore ${ }^{\circledR}$, Darmstadt, Germany), and the filter was washed with deionised water. The filter was dried at $80^{\circ} \mathrm{C}$ until the mass remained stable. The difference in mass between the filter before and after filtration gave the cell dry mass (CDM) concentration ( $g \cdot C D M / L)$. For the OD measurements, absorption of the cell suspension was determined at a wavelength of $600 \mathrm{~nm}$. Biomass measurements were performed in triplicate, and the standard deviation was calculated to represent the error bars. First-order growth kinetics was used to fit the exponential part of the growth curve and to determine the maximum specific growth rate.

\subsection{Flocculation Assay}

The assay was based on the method of D'Hautcourt and Smart [37], with slight modifications. Cells were grown for $24 \mathrm{~h}$ in $20 \mathrm{~mL}$ YPD. The cell suspension was centrifuged (4000 rpm, $3 \mathrm{~min}$ ), and the medium was discarded. Subsequently, the cells were resuspended in an equal volume of EDTA-buffer to chelate the $\mathrm{Ca}^{2+}$-ions and deflocculate the yeast flocs. The $\mathrm{OD}_{600 \mathrm{~nm}}$-value of the suspension was determined, and such a volume was transferred to an Eppendorf tube to ensure an $\mathrm{OD}_{600 \mathrm{~nm}}$-value of 10 in $1 \mathrm{~mL}$. EDTA (ethylenediaminetetraacetic acid)-buffer (50 mM EDTA, pH 7) was added until a final volume of $1 \mathrm{~mL}$ was acquired. A sample of $50 \mu \mathrm{L}$ was taken $0.5 \mathrm{~mL}$ below the meniscus, and the sample was diluted 20 times in a $1.5 \mathrm{~mL}$ cuvette with EDTA-buffer. The tubes were centrifuged (4000 rpm, $3 \mathrm{~min}$ ), and the supernatant was discarded. The cells were resuspended in $1 \mathrm{~mL}$ flocculation buffer $\mathrm{A}\left(3 \mathrm{mM} \mathrm{CaSO}_{4}\right)$. The last step was repeated, but the cells were resuspended in flocculation buffer B ( $3 \mathrm{mM} \mathrm{CaSO}_{4}, 83 \mathrm{mM} \mathrm{CH}_{3} \mathrm{COONa}, 4 \% v / v$ ethanol, $\left.\mathrm{pH} 4.5\right)$. The tubes were shaken horizontally at $100 \mathrm{rpm}$ for $10 \mathrm{~min}$. Prior to taking $50 \mu \mathrm{L}$ samples $0.5 \mathrm{~mL}$ below the meniscus, 3 min of sedimentation in a vertical position took place. The sample was diluted 20 times with EDTA-buffer in a $1.5 \mathrm{~mL}$ cuvette. The absorbance of both suspensions in the cuvettes was determined, and the related flocculation percentage was calculated:

$$
\text { Flocculation percentage }(\%)=\frac{\text { OD }_{\text {EDTA }}-\text { OD }_{\text {Flocculation buffer }}}{\text { OD }_{\text {EDTA }}} \times 100
$$

with $\mathrm{OD}_{\mathrm{EDTA}}$ as the $\mathrm{OD}_{600 \mathrm{~nm}}$-value of cells in EDTA-buffer, and $\mathrm{OD}_{\text {Flocculation buffer }}$ the $\mathrm{OD}_{600 \mathrm{~nm}}$-value of cells in flocculation buffer B.

\subsection{Biocompatibility Assay}

A commercial resin (Clear Resin GPCL02, FormLabs, Somerville, MA, USA) composed of a mixture of methacrylic acid esters and photoinitiators was used to print the mini reactor. To ensure that this resin had no negative effect on the growth of yeast cells, a biocompatibility assay was performed. Therefore, four sterile Erlenmeyer flasks were filled with $50 \mathrm{~mL}$ YPD. Prior to adding a piece of resin to two of the four flasks, the pieces were rinsed with soap water, ethanol, and sterile water. Afterwards, all flasks were inoculated with $4 \mathrm{~mL}$ of a preculture of the $S$. cerevisiae BY4742 strain in such a way that a final $\mathrm{OD}_{600 \mathrm{~nm}}$-value of 0.2 was reached. The flasks were incubated at $30^{\circ} \mathrm{C}$ and shaken at $120 \mathrm{rpm}$. Every two hours, a $1 \mathrm{~mL}$ sample was taken from each flask, and the cell concentration was determined. 


\subsection{Mini Tower Fermentor Design and Construction}

The mini tower reactor was designed in COMSOL Multiphysics 4.4 (Stockholm, Sweden). The bioreactor had a high-aspect-ratio (beer depth divided by the inner diameter) of around 8:1, which is based on the APV tower fermentor that was used to produce lager and ale beer in the 1960s [30,31,38,39]. The inlet tube had an inner radius of $1 \mathrm{~mm}$ and a length of $18 \mathrm{~mm}$; the outlet tube had an inner radius of $2 \mathrm{~mm}$ and a length of $25 \mathrm{~mm}$; both contained barbs to facilitate the attachment of the silicone tubing. The bottom of the vessel was conical with a bottom inner radius of $0.7 \mathrm{~mm}$, a top radius of $5.5 \mathrm{~mm}$, and a wall thickness of $1 \mathrm{~mm}$ (Figure 1F). The mid cylindrical part was $88 \mathrm{~mm}$ high and had an inner radius of $5.5 \mathrm{~mm}$. Another cone connected the cylinder to the reactor head. This cone had a bottom inner radius of $5.5 \mathrm{~mm}$, a top inner radius of $11 \mathrm{~mm}$, and a height of $11 \mathrm{~mm}$. A conical opening was incorporated in the reactor head with a bottom radius of $7.5 \mathrm{~mm}$, a top inner radius of $9 \mathrm{~mm}$, and a height of $20 \mathrm{~mm}$. The dimensions of this opening fitted a silicone stopper that was pierced with a hypodermic needle (sharp 18G, $150 \mathrm{~mm}$, Samco, Surrey, UK), allowing the reactor to be aerated at the bottom cone.

The benchtop SLA 3D printer Form 1+ (Formlabs, Somerville, MA, USA) was used to construct the bioreactor. The COMSOL Multiphysics design was exported as an "stl" file and imported in the printing software PreForm 2 (Formlabs, Somerville, MA, USA). A layer thickness of $0.05 \mathrm{~mm}$ was selected for the printing job. Supports settings were: a density of 1 , point size of $0.6 \mathrm{~mm}$, and selection of no internal supports. The reactor was oriented with the top of the reactor towards the base, under an angle of $20^{\circ}$ around the $z$-axis. The printed structure was shaken gently in two consecutive isopropanol baths, and was sterilised by autoclaving $\left(121^{\circ} \mathrm{C}, 20 \mathrm{~min}\right)$.

In preliminary experiments, the design was optimised by performing short-term cultivations with a strong flocculating yeast strain (BY4742 [FLO1]). The design adaptations are illustrated in Figure 1A-F). The medium was fed through the bottom inlet, and was disposed through the middle outlet. To prevent flocs from sedimenting through the inlet tube, the inner radius of the inlet was decreased to obtain a higher medium inlet velocity (Figure 1B-F versus A). In the initial designs (Figure 1A-D), a gas outlet was present at the top of the reactor. To enhance the medium flow through the reactor, this outlet was removed in the final design, and gases were removed via the liquid outlet. The inlet and outlet were modified by printing of barbs at the outsides, which allowed the silicone tubing to be attached strongly using plastic straps (Figure 1G). The bottom of the vessel was conical, which facilitated sedimentation and fluidisation of the yeast flocs. The body of the reactor was a long cylinder. The wider cylindrical reactor head was connected to the body by another cone to avoid floc retention within the reactor head. Therefore, the length and slope of this cone was increased from the second design on. A conical opening was incorporated in the reactor head and fitted with a silicone stopper. This allowed the reactor to be gently aerated and fluidised from the bottom by piercing the silicone stopper with a long needle.

A

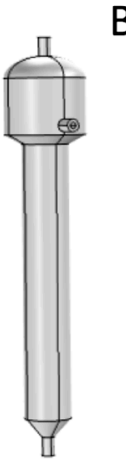

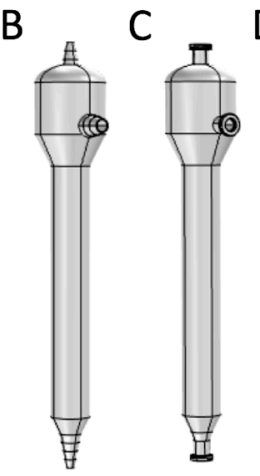

$\mathrm{E}$

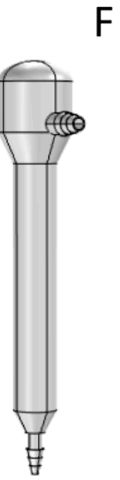

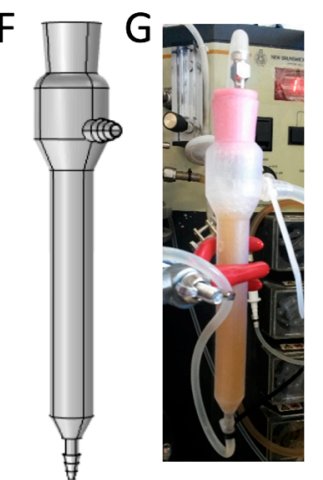

Figure 1. The chronological stages in the development of the 3D-printed mini tower fermentor (A-F); (G) the printed reactor $\mathbf{F}$ setup during the evolution experiment. 


\subsection{Mini Tower Fermentor Mathematical Modelling}

To evaluate the effect of gravity as selective pressure within the mini tower reactor, fluid flow and particle tracing simulations were performed in COMSOL Multiphysics 4.4 by selecting the Fluid Flow (Single-Phase Flow, Laminar Flow) and the Particle Tracing for Fluid Flow physics. Water at $20{ }^{\circ} \mathrm{C}$ was selected as the working liquid (density $999.62 \mathrm{~kg} / \mathrm{m}^{3}$, dynamic viscosity $0.001 \mathrm{~Pa} \cdot \mathrm{s}$ ). Laminar fluid flow through the reactor was simulated with laminar inflow as boundary condition at the inlet. An inlet flow rate of $1.47 \mathrm{~mL} / \mathrm{h}$ (with an entrance length of $5 \mathrm{~cm}$ ) was employed, which was in agreement with the initial flow rate of the actual experiment (see Section 2.7). Pressure (atmospheric pressure) was selected as the boundary condition at the outlet, and backflow was suppressed. Physics-controlled mesh was selected as mesh settings with normal element size. Particle Tracing for Fluid flow was used to calculate the motion of the particles in a background laminar fluid flow. Three thousand particles were released at the inlet, with a random diameter between $3 \mu \mathrm{m}$ and $70 \mu \mathrm{m}$. This range includes the size of planktonic cells as well as small yeast flocs. The density of the particles was set at $1117 \mathrm{~kg} / \mathrm{m}^{3}$, which is the average of values found in the literature [40-43]. The particles were released at the inlet (bottom) of the reactor. The forces acting on the particles are the drag force of the fluid and the gravity force.

\subsection{Experimental Set-Up}

A fermentation vessel (5 L) (BioFlo III, New Brunswick Scientific, Edison, NJ, USA), which was aerated, agitated at $137 \mathrm{rpm}$, and heated to $32{ }^{\circ} \mathrm{C}$, was used as medium reservoir, and connected to the mini tower fermentor inlet with silicone tubing (Figure 1G). The peristaltic pump of the BioFlo III fermentor was used as feeding pump. This pump was initially set at a flow rate of $1.47 \mathrm{~mL} / \mathrm{h}$, which corresponds to a dilution rate of $0.11 \mathrm{~h}^{-1}$. A silicone stopper was inserted in the mini reactor head and was pierced by a needle to reach the bottom of the reactor. The needle was connected to an aquarium pump to aerate the reactor. The outlet of the reactor was connected to a four-port manifold. Each outlet of the manifold was connected to a needle head. This needle was pierced through a silicone stopper, which was put in a 15- or 50-mL Falcon tube. The manifold enabled fast and simple exchanging of the outlet reservoir. The four Falcon tubes were permanently kept on ice. Inoculation was performed by piercing a syringe through the silicone stopper and ejecting the inoculum directly into the mini reactor.

\section{Results}

\subsection{Simulation of Single Cell and Cell Aggregate Behaviour in the Mini Tower Fermentor}

A tower fermentor is suitable to exploit gravity as selective pressure in evolution experiments, since aggregates will be retained preferentially in the reactor compared to single cells. The selective pressure within the tower fermentor was evaluated by particle tracing simulations in COMSOL Multiphysics. Only particles with a diameter smaller than approximately $11 \mu \mathrm{m}$ were able to reach the top of the reactor (Figure 2). This corresponds to single cells or possibly a complex of two or three cells. According to the calculations, it is very unlikely for larger particles (such as flocs) to reach the outlet of the reactor. Over a longer period of time, this would result in an amplification of flocculating cells within the fermentor. Cells are also retained at the locations of the conical structures. These simulations do not take into account the upward air flow or $\mathrm{CO}_{2}$ release by the cells during cultivation, which will increase the flow through the reactor. As experimentally demonstrated (see further), these latter conditions also result in a higher probability of cell aggregate retention in the reactor. 


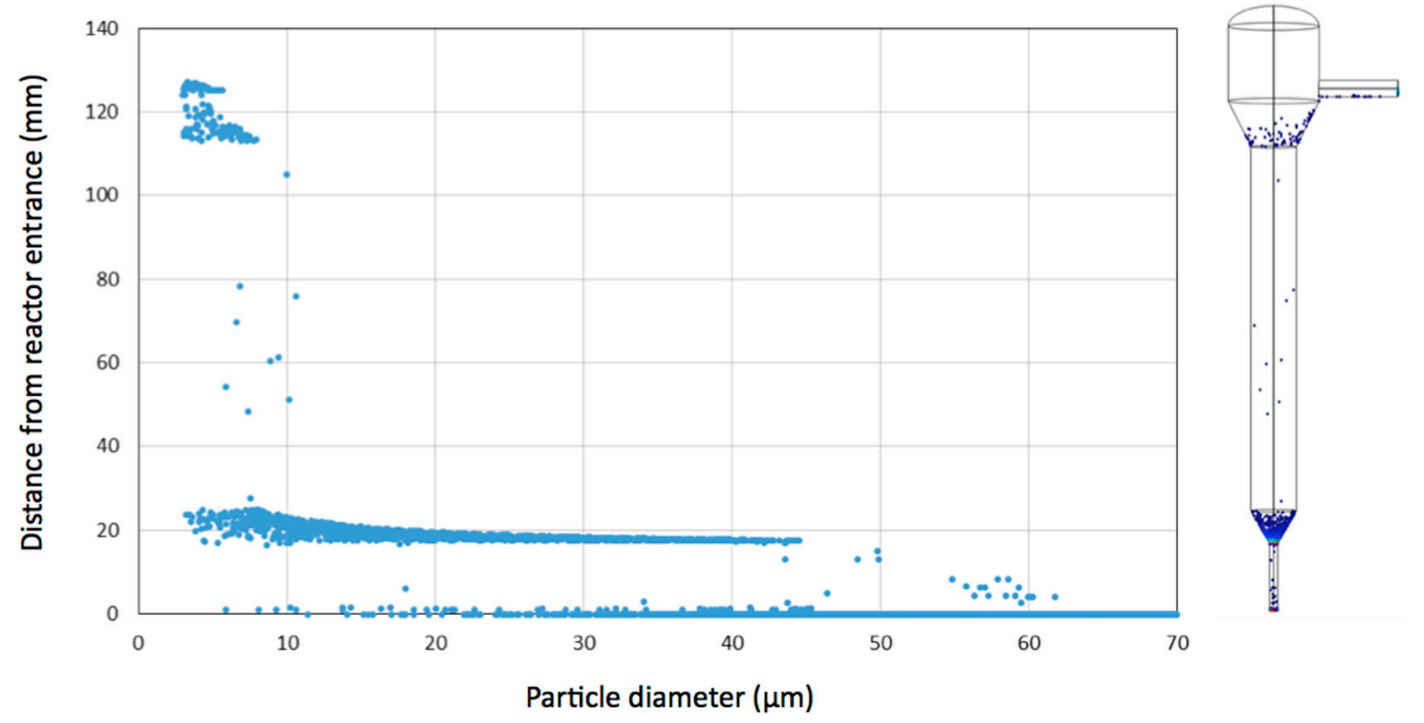

Figure 2. Particle tracing in a 3D-printed bioreactor using COMSOL Multiphysics. The distance travelled from the reactor entrance is plotted against the cell particle diameter.

\subsection{Biocompatibility Assay}

To ensure that the used resin for the construction of the reactor did not have any negative effects on the growth of the obtained yeast strains, a biocompatibility assay was performed. The S. cerevisiae BY4742 strain was grown in the presence and absence of a printed structure. The printed resin material had no effect on the growth of the yeast cells (see Appendix A: Figure A1). The maximum specific growth rate in the presence and absence of the resin material were comparable $\left(0.21 \mathrm{~h}^{-1}\right.$ and $0.22 \mathrm{~h}^{-1}$, respectively), indicating the yeast growth biocompatibility of the polymeric material.

\subsection{Adaptive Evolution during Continuous Operation}

The mini tower fermentor was used for an evolution experiment with the intention of obtaining a more flocculent phenotype of an industrial brewer's strain. The strain was characterised by a very low flocculation percentage $(4 \% \pm 6 \%)$. The conditions inside the tower fermentor were monitored by sampling at the exit, and by measuring the $\mathrm{pH}$ and cell density (Figure 3 ). The cultivation was initiated with a dilution rate of approximately $0.1 \mathrm{~h}^{-1}$. The cell concentration visibly increased inside the reactor over time. The dilution rate was increased in steps to avoid wash-out and selectively retain larger cell aggregates. The dilution rate was doubled after seven days, which resulted in an increased biomass concentration. The dilution rate was further increased up to $0.4 \mathrm{~h}^{-1}$. At this rate, a dense yeast slurry containing cell aggregates was present in the reactor. The experiment was ended after 14 days of continuous culture when a dense yeast slurry could be visually observed in the reactor.

The yeast population was subsequently examined by optical microscopy (Figure 4). The presence of multicellular yeast flocs was observed. The morphology of the flocs can be described as "snowflake" aggregates. Yeast cell clusters with a comparable morphology have been recently described [44-46]. The evolved cells were plated out on WL nutrient agar, which can be used to detect morphological differences between strains [36]. The population at the start, and after seven and fifteen days were compared (Figure 5). The CMBSVM22 strain possesses the FLO11 gene required for invasive growth [32,47-49], which could clearly be seen on the bottom of the plates. The morphology of the colonies differed after 14 days, the same time when the snowflake flocs were observed. Most likely, a mixture of multicellular clusters and single cells was spotted, causing the presence of radial differences in colony colour. A flocculation assay was attempted, but the aggregates could not be 
deflocculated by adding deflocculation buffer. Deflocculation was also not successful after sonication and heating up to $90{ }^{\circ} \mathrm{C}$ during $15 \mathrm{~min}$ in the presence of $8 \mathrm{M}$ urea.

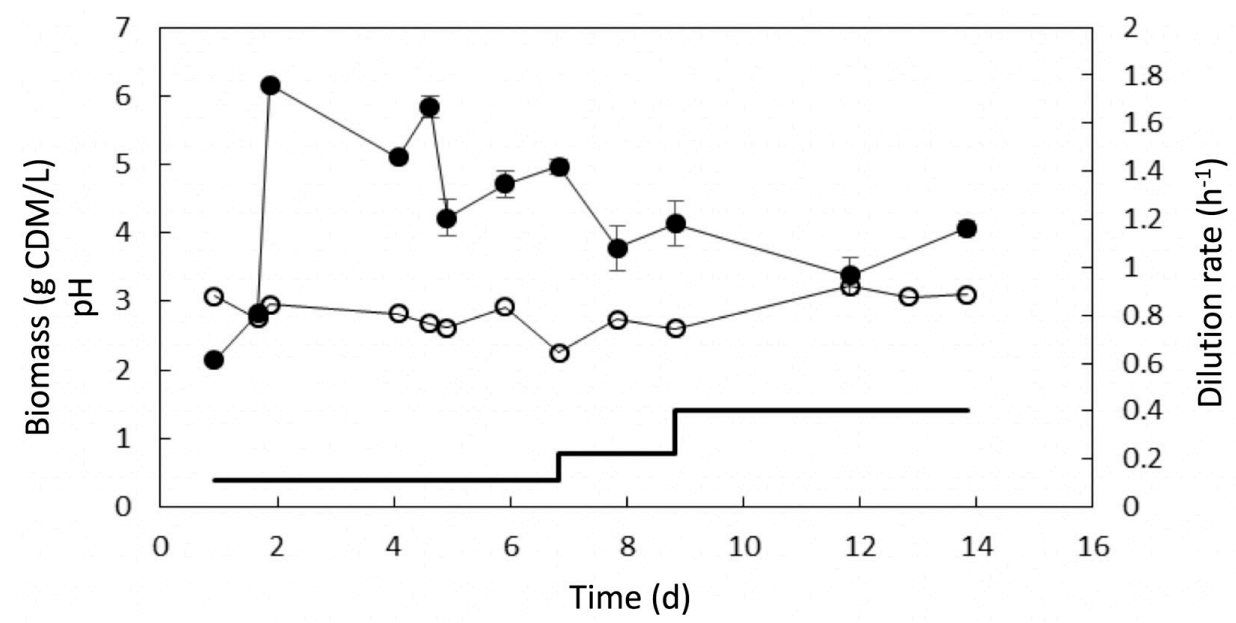

Figure 3. Cultivation of CMBSVM22 in the 3D-printed continuous mini bioreactor. The evolution of the biomass concentration ( $\mathrm{g} \cdot$ cell dry mass $(\mathrm{CDM}) / \mathrm{L})(\bullet)$ of the effluent stream, the $\mathrm{pH}(\bigcirc)$, and the dilution rate $(-)$ during the evolution experiment.

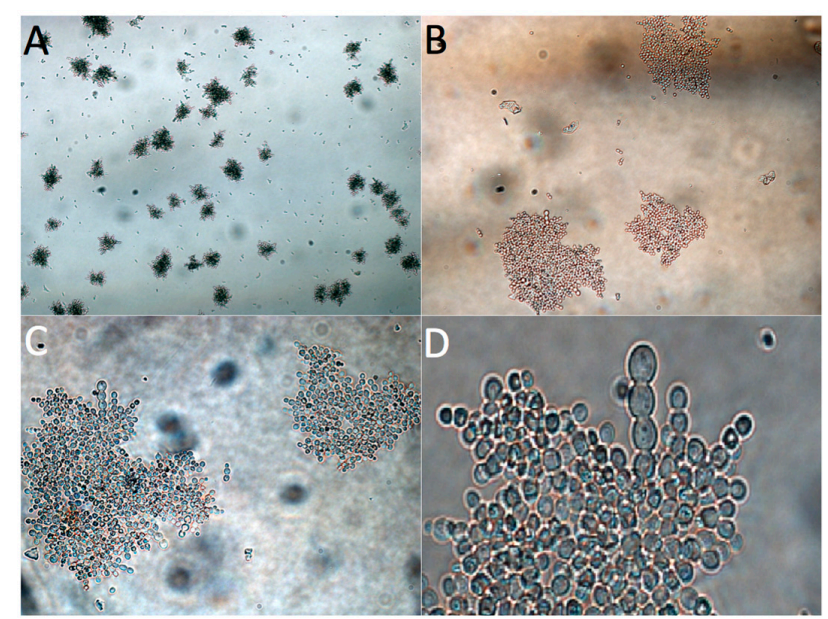

Figure 4. Microscopic observations of snowflake flocs at the end of the fermentation. Objectives: (A) $10 \times$; (B) $20 \times$; (C) zoom-in of $40 \times$; (D) $10 \times$.
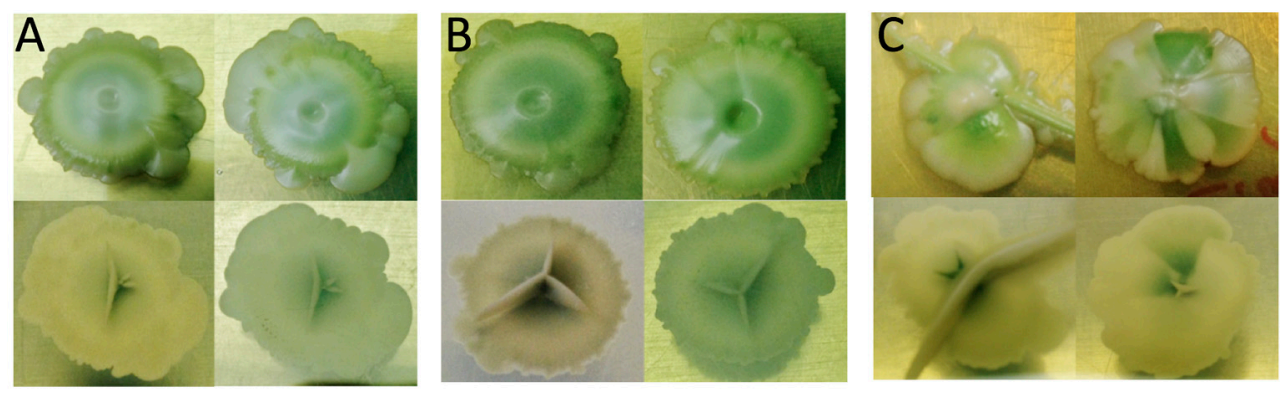

Figure 5. Colonies of CMBSVM22 grown on WL nutrient agar plates. Top (upper panels) and bottom (lower panels) view of two colonies at (A) the start of the cultivation; (B) after 7 days of cultivation; and (C) after 14 days of cultivation. 


\section{Discussion}

A 3D-printed reactor was created, based on an industrial tower fermentor. The reactor is characterized by a high aspect-ratio, which creates a gravity-based selective pressure: single cells have a higher probability to be washed out than cell aggregates, as the denser aggregates tend to sediment faster. Consequently, this reactor type ensures excellent conditions for strain evolution towards a more aggregative phenotype.

We used a commercial physics modelling software package that includes 3D modelling tools. The created 3D model can be exported as an "stl" file that was imported in the print program. The flow of particles such as yeast cells and flocs in the 3D model of the tower fermentor was calculated with the modelling software. In silico simulations confirmed the gravity-based selective pressure in the reactor, and the theoretical retainment advantage of aggregating cells in the reactor was demonstrated.

The employment of 3D-printing for the development of a bioprocess has several advantages. As demonstrated in this contribution, the flexibility of adapting the design allows the design to be optimized quickly. Depending on the selected print resolution, the mini reactor can be printed in a few hours (4-7 h). The used commercial resin is biocompatible, and the printed structure can be autoclaved. We selected transparent resin, which allowed visual observation of the content.

A long-term continuous cultivation experiment was performed to improve the flocculation characteristics of a brewer's ale strain. Cell flocculation is of particular interest to the brewing industry, since it simplifies yeast removal at the end of the fermentation [29]. Still, many industrial brewing strains show no adequate flocculation. ALE is an interesting method to adapt the strain, since genetic manipulation - which is not allowed in the manufacture of products for human consumption-is not involved. At the end of the evolution experiment, yeast cell aggregates were observed with "snowflake" morphology. These multicellular structures did not disaggregate in EDTA buffer nor urea buffer, which indicates that the Flo proteins are not involved in the aggregation mechanism [50,51]. A high temperature of $90{ }^{\circ} \mathrm{C}$ could also not destroy the aggregates, which confirms that the aggregation mechanism is not flocculin-based, since these flocs can be disaggregated above $60{ }^{\circ} \mathrm{C}$ [50].

A similar morphology of yeast cell clusters was observed when mother/daughter separation was impaired [46]. This phenotype was recently discovered by performing a gravity-based repeated batch evolution experiment with a diploid S. cerevisiae Y55 strain where sedimented cells were collected and cultivated further in a next batch culture [44]. It was demonstrated that these multicellular clusters are uniclonal and appeared as "snowflakes". This phenotype was also obtained in an ALE experiment with a haploid S. cerevisiae CEN.PK113-7D strain using long-term cultivation in sequential batch reactors [45]. It was shown that a frameshift mutation in ACE2-which encodes a transcriptional regulator involved in cell cycle control and mother-daughter cell separation (MDS)—caused the snowflake phenotype. The disruption of the transcription factor Ace2p prevented the splitting of mother and daughter cell [52], and affected the expression of its targets. One of the targets of Ace2p is Cts1p, which is a chitinase that is required for the degradation of the cell septum. Gene expression of CTS1 was approximately $90 \%$ reduced in the evolved strain [45]. Six other genes (DSE4, DSE2, SUN4, DSE1, SCW11, and AMN1) that are regulated by ACE2 were significantly downregulated in the snowflake yeast [46]. These seven downregulated genes are involved in daughter cell separation, many acting directly to degrade the bud neck septum as MDS enzymes [52-55]. It was shown that $A C E 2$ knockouts formed cellular clusters $[45,53,56,57]$. The knockout of $C B K 1$ (a serine/threonine protein kinase of the RAM signalling network that regulates localisation and activity of Ace2p and the Ssd1p translation repressor) also results in cell clusters $[56,58,59]$. These results indicate that a lack of the degradation of the septum between the mother and daughter cells could explain the observed multicellular clusters. Whole genome sequencing of the evolved strain that was obtained in the current experiment is necessary to find out if the observed aggregates are the result of (a) mutation(s) in genes involved in MDS, or if mutations in other genes can also result in the snowflake phenotype. 


\section{Conclusions}

A continuous mini tower fermentor was designed and constructed using a 3D printer. The printed fermentor was biocompatible for yeast cultivation and could be sterilized by autoclaving. The tower fermentor was suitable to perform experimental evolution experiments where gravity acts as the selective pressure, and allowed yeast cells to evolve from planktonic single cells towards cell aggregates. After 14 days of continuous cultivation of a non-flocculating industrial brewer's yeast strain in the fermentor, yeast flocs with a "snowflake" morphology were observed. Yeast floc characterisation showed that the cell-cell interactions in the cell aggregates were not the result of flocculin interactions, but probably the result of (a) mutation(s) in gene(s) that are involved in the mother/daughter separation process.

Acknowledgments: The Belgian Federal Science Policy Office (Belspo) and the European Space Agency (ESA) PRODEX program supported this work. The Research Council of the Vrije Universiteit Brussel (Belgium) and the University of Ghent (Belgium) are acknowledged to support the Alliance Research Group VUB-UGent NanoMicrobiology (NAMI), and the International Joint Research Group (IJRG) VUB-EPFL BioNanotechnology \& NanoMedicine (NANO).

Author Contributions: Ronnie G. Willaert and Andreas Conjaerts conceived and designed the experiments; Andreas Conjaerts performed the experiments; Andreas Conjaerts and Ronnie G. Willaert analysed the data; Ronnie G. Willaert contributed reagents/materials/analysis tools; Ronnie G. Willaert and Andreas Conjaerts wrote the paper.

Conflicts of Interest: The authors declare no conflict of interest.

\section{Appendix A}

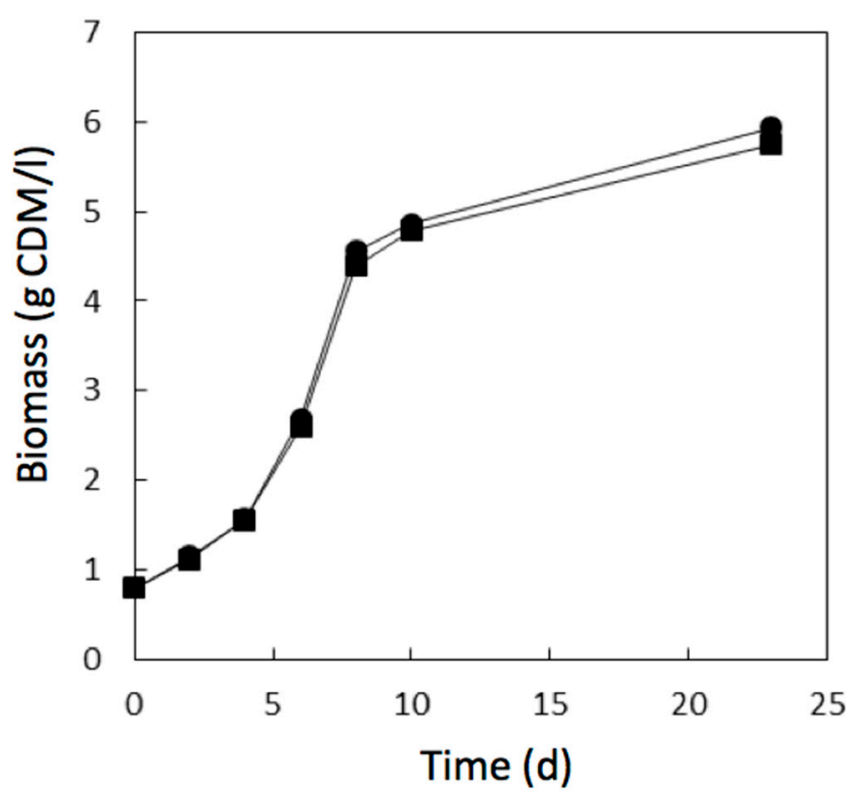

Figure A1. Biocompatibility assay of S. cerevisiae BY4742. Evolution of the biomass concentration in the presence $(\bullet)$ and absence $(\boldsymbol{\square})$ of the methacrylic acid ester resin printed material during 1 day of growth.

\section{References}

1. Dequin, S. The potential of genetic engineering for improving brewing, wine-making and baking yeasts. Appl. Microbiol. Biotechnol. 2001, 56, 577-588. [CrossRef] [PubMed]

2. Saerens, S.M.; Duong, C.T.; Nevoigt, E. Genetic improvement of brewer's yeast: Current state, perspectives and limits. Appl. Microbiol. Biotechnol. 2010, 86, 1195-1212. [CrossRef] [PubMed]

3. Conrad, T.M.; Lewis, N.E.; Palsson, B.Ø. Microbial laboratory evolution in the era of genome-scale science. Mol. Syst. Biol. 2011, 7, 509. [CrossRef] [PubMed] 
4. Portnoy, V.A.; Bezdan, D.; Zengler, K. Adaptive laboratory evolution-Harnessing the power of biology for metabolic engineering. Curr. Opin. Biotechnol. 2011, 22, 590-594. [CrossRef] [PubMed]

5. Dragosits, M.; Mattanovich, D. Adaptive laboratory evolution-Principles and applications for biotechnology. Microb. Cell Fact. 2013, 12, 64. [CrossRef] [PubMed]

6. Gibson, B.; Liti, G. Saccharomyces pastorianus: Genomic insights inspiring innovation for industry. Yeast 2015, 32, 17-27. [CrossRef] [PubMed]

7. Blieck, L.; Toye, G.; Dumortier, F.; Verstrepen, K.J.; Delvaux, F.R.; Thevelein, J.M.; van Dijck, P. Isolation and characterization of brewer's yeast variants with improved fermentation performance under high-gravity conditions. Appl. Environ. Microbiol. 2007, 73, 815-824. [CrossRef] [PubMed]

8. Huuskonen, A.; Markkula, T.; Vidgren, V.; Lima, L.; Mulder, L.; Geurts, W.; Walsh, M.; Londesborough, J. Selection from industrial lager yeast strains of variants with improved fermentation performance in very-high-gravity worts. Appl. Environ. Microbiol. 2010, 76, 1563-1573. [CrossRef] [PubMed]

9. Yu, Z.; Zhao, H.; Li, H.; Zhang, Q.; Lei, H.; Zhao, M. Selection of Saccharomyces pastorianus variants with improved fermentation performance under very high gravity wort conditions. Biotechnol. Lett. 2012, 34, 365-370. [CrossRef] [PubMed]

10. James, T.C.; Usher, J.; Campbell, S.; Bond, U. Lager yeasts possess dynamic genomes that undergo rearrangements and gene amplification in response to stress. Curr. Genet. 2008, 53, 139-152. [CrossRef] [PubMed]

11. Ekberg, J.; Rautio, J.; Mattinen, L.; Vidgren, V.; Londesborough, J.; Gibson, B.R. Adaptive evolution of the lager brewing yeast Saccharomyces pastorianus for improved growth under hyperosmotic conditions and its influence on fermentation performance. FEMS Yeast Res. 2013, 13, 335-349. [CrossRef] [PubMed]

12. Strejc, J.; Siř́ístova, L.; Karabín, M.; Almeida e Silva, J.B.; Brányik, T. Production of alcohol-free beer with elevated amounts of flavouring compounds using lager yeast mutants. J. Inst. Brew. 2013, 119, 149-155. [CrossRef]

13. Cadière, A.; Ortiz-Julien, A.; Camarasa, C.; Dequin, S. Evolutionary engineered Saccharomyces cerevisiae wine yeast strains with increased in vivo flux through the pentose phosphate pathway. Metab. Eng. 2011, 13, 263-271. [CrossRef] [PubMed]

14. Cadière, A.; Aguera, E.; Caillé, S.; Ortiz-Julien, A.; Dequin, S. Pilot-scale evaluation the enological traits of a novel, aromatic wine yeast strain obtained by adaptive evolution. Food Microbiol. 2012, 32, 332-337. [CrossRef] [PubMed]

15. Dunham, M.J.; Kerr, E.O.; Miller, A.W.; Payen, C. Chemostat culture for yeast physiology and experimental evolution. Cold Spring Harb. Protoc. 2016. [CrossRef]

16. Miller, A.W.; Befort, C.; Kerr, E.O.; Dunham, M.J. Design and use of multiplexed chemostat arrays. J. Vis. Exp. 2013, 72, e50262. [CrossRef] [PubMed]

17. Kumar, S.; Wittmann, C.; Heinzle, E. Minibioreactors. Biotechnol. Lett. 2004, 26, 1-10. [CrossRef] [PubMed]

18. Betts, J.I.; Baganz, F. Miniature bioreactors: Current practices and future opportunities. Microb. Cell Fact. 2006, 5, 21. [CrossRef] [PubMed]

19. Hortsch, R.; Weuster-Botz, D. Milliliter-scale stirred tank reactors for the cultivation of microorganisms. Adv. Appl. Microbiol. 2010, 73, 61-82. [PubMed]

20. Tuomi, J.; Paloheimo, K.S.; Vehviläinen, J.; Björkstrand, R.; Salmi, M.; Huotilainen, E.; Kontio, R.; Rouse, S.; Gibson, I.; Mäkitie, A.A. A novel classification and online platform for planning and documentation of medical applications of additive manufacturing. Surg. Innov. 2014, 21, 553-559. [CrossRef] [PubMed]

21. Mironov, V.; Boland, T.; Trusk, T.; Forgacs, G.; Markwald, R.R. Organ printing: Computer-aided jet-based 3D tissue engineering. Trends Biotechnol. 2003, 21, 157-161. Erratum in: Trends Biotechnol. 2004, 22, 265. [CrossRef]

22. Mironov, V.; Kasyanov, V.; Markwald, R.R. Organ printing: From bioprinter to organ biofabrication line. Curr. Opin. Biotechnol. 2011, 22, 667-673. [CrossRef] [PubMed]

23. Leukers, B.; Gülkan, H.; Irsen, S.H.; Milz, S.; Tille, C.; Schieker, M.; Seitz, H. Hydroxyapatite scaffolds for bone tissue engineering made by 3D printing. J. Mater. Sci. Mater. Med. 2005, 16, 1121-1124. [CrossRef] [PubMed]

24. Salmi, M. Possibilities of preoperative medical models made by 3D printing or additive manufacturing. J. Med. Eng. 2016, 2016, 6191526. [CrossRef] [PubMed] 
25. Sears, N.A.; Seshadri, D.R.; Dhavalikar, P.S.; Cosgriff-Hernandez, E. A review of three-dimensional printing in tissue engineering. Tissue Eng. Part B Rev. 2016, 22, 298-310. [CrossRef] [PubMed]

26. Dong, Y.; Fan, S.Q.; Shen, Y.; Yang, J.X.; Yan, P.; Chen, Y.P.; Li, J.; Guo, J.S.; Duan, X.M.; Fang, F.; et al. A novel bio-carrier fabricated using 3D printing technique for wastewater treatment. Sci. Rep. 2015, 5, 12400. [CrossRef] [PubMed]

27. Gross, B.C.; Erkal, J.L.; Lockwood, S.Y.; Chen, C.; Spence, D.M. Evaluation of 3D printing and its potential impact on biotechnology and the chemical sciences. Anal. Chem. 2014, 86, 3240-3253. [CrossRef] [PubMed]

28. Melchels, F.P.; Feijen, J.; Grijpma, D.W. A review on stereolithography and its applications in biomedical engineering. Biomaterials 2010, 31, 6121-6130. [CrossRef] [PubMed]

29. Boulton, C.; Quain, D. Fermentation systems. In Brewing Yeast and Fermentation; Blackwell Science Ltd.: Oxford, UK, 2001; pp. 260-372.

30. Klopper, W.J.; Roberts, R.H.; Royston, M.G.; Ault, R.G. Continuous fermentation in a tower fermenter. Proc. Eur. Brew. Conv. 1965, 238-259.

31. Ault, R.G.; Hampton, A.N.; Newton, R.; Roberts, R.H. Biological and biochemical aspects of tower fermentation. J. Inst. Brew. 1969, 75, 260-277. [CrossRef]

32. Van Mulders, S.E.; Ghequire, M.; Daenen, L.; Verbelen, P.J.; Verstrepen, K.J.; Delvaux, F.R. Flocculation gene variability in industrial brewer's yeast strains. Appl. Microbiol. Biotechnol. 2010, 88, 1321-1331. [CrossRef] [PubMed]

33. Brachmann, C.B.; Davies, A. Designer deletion strains derived from Saccharomyces cerevisiae S288C: A useful set of strains and plasmids for PCR-mediated gene disruption and other applications. Yeast 1998, 14, 115-132. [CrossRef]

34. Van Mulders, S.E.; Christianen, E.; Saerens, S.M.G.; Daenen, L.; Verbelen, P.J.; Willaert, R.; Verstrepen, K.J.; Delvaux, F.R. Phenotypic diversity of Flo protein family-mediated adhesion in Saccharomyces cerevisiae. FEMS Yeast Res. 2009, 9, 178-190. [CrossRef] [PubMed]

35. Richards, M. The use of giant-colony morphology for the differentiation of brewing yeasts. J. Inst. Brew. 1967, 73, 162-166. [CrossRef]

36. Pallmann, C.L.; Brown, J.A.; Olineka, T.L.; Cocolin, L.; Mills, D.A.; Bisson, L.F. Use of WL medium to profile native flora fermentations. Am. J. Enol. Vitic. 2001, 52, 198-203.

37. D'Hautcourt, O.; Smart, K.A. Measurement of brewing yeast flocculation. J. Am. Soc. Brew. Chem. 1999, 57, 123-128.

38. Den Blanken, J.G. The tower fermenter for lager beer production. Brew. Gardian 1974, 35-39.

39. Seddon, A.W. Continuous tower fermentation-Experiences in establishing large scale commercial production. Brewer 1976, 72-78.

40. Haddad, S.A.; Lindegren, C.C. A method for determining the weight of an individual yeast cell. Appl. Microbiol. 1953, 1, 153-156. [PubMed]

41. Davis, R.H.; Hunt, T.P. Modeling and measurement of yeast flocculation. Biotechnol. Prog. 1986, 2, 91-97. [CrossRef] [PubMed]

42. Fontana, A.; Bore, C.; Ghommidh, C.; Guiraud, J.P. Structure and sucrose hydrolysis activity of Saccharomyces cerevisiae aggregates. Biotechnol. Bioeng. 1992, 40, 475-482. [CrossRef] [PubMed]

43. Van Hamersveld, E.H.; Van Der Lans, R.G.; Luyben, K.C. Quantification of brewers' yeast flocculation in a stirred tank: Effect of physical parameters on flocculation. Biotechnol. Bioeng. 1997, 56, 190-200. [CrossRef]

44. Ratcliff, W.C.; Denison, R.F.; Borrello, M.; Travisano, M. Experimental evolution of multicellularity. Proc. Natl. Acad. Sci. USA 2012, 109, 1595-1600. [CrossRef] [PubMed]

45. Oud, B.; Guadalupe-Medina, V.; Nijkamp, J.F.; de Ridder, D.; Pronk, J.T.; van Maris, A.J.; Daran, J.M. Genome duplication and mutations in ACE2 cause multicellular, fast-sedimenting phenotypes in evolved Saccharomyces cerevisiae. Proc. Natl. Acad. Sci USA 2013, 110, E4223-E4231. [CrossRef] [PubMed]

46. Ratcliff, W.C.; Fankhauser, J.D.; Rogers, D.W.; Greig, D.; Travisano, M. Origins of multicellular evolvability in snowflake yeast. Nat. Commun. 2015, 6, 6102. [CrossRef] [PubMed]

47. Guo, B.; Styles, C.A.; Feng, Q.; Fink, G.R. A Saccharomyces gene family involved in invasive growth, cell-cell adhesion, and mating. Proc. Natl. Acad. Sci. USA 2000, 97, 12158-12163. [CrossRef] [PubMed]

48. Goossens, K.V.; Willaert, R.G. The N-terminal domain of the Flo11 protein from Saccharomyces cerevisiae is an adhesin without mannose-binding activity. FEMS Yeast Res. 2012, 12, 78-87. [CrossRef] [PubMed] 
49. Kraushaar, T.; Brückner, S.; Veelders, M.; Rhinow, D.; Schreiner, F.; Birke, R.; Pagenstecher, A.; Mösch, H.U.; Essen, L.O. Interactions by the fungal Flo11 adhesin depend on a fibronectin Type III-like adhesin domain girdled by aromatic bands. Structure 2015, 23, 1005-1017. [CrossRef] [PubMed]

50. Mill, P.J. The nature of the interactions between flocculent cells in the flocculation of Saccharomyces cerevisiae. J. Gen. Microbiol. 1964, 35, 61-68. [CrossRef] [PubMed]

51. Stratford, M.; Keenan, M.H. Yeast flocculation: Quantification. Yeast 1988, 4, 107-115. [CrossRef] [PubMed]

52. Weiss, E.L. Mitotic exit and separation of mother and daughter cells. Genetics 2012, 192, 1165-1202. [CrossRef] [PubMed]

53. King, L.; Butler, G. Ace2p, a regulator of CTS1 (chitinase) expression, affects pseudohyphal production in Saccharomyces cerevisiae. Curr. Genet. 1998, 34, 183-191. [CrossRef] [PubMed]

54. O'Conallain, C.; Doolin, M.T.; Taggart, C.; Thornton, F.; Butler, G. Regulated nuclear localisation of the yeast transcription factor Ace2p controls expression of chitinase (CTS1) in Saccharomyces cerevisiae. Mol. Gen. Genet. 1999, 262, 275-282. [CrossRef] [PubMed]

55. McBride, H.J.; Yu, Y.; Stillman, D.J. Distinct regions of the Swi5 and Ace2 transcription factors are required for specific gene activation. J. Biol. Chem. 1999, 274, 21029-21036. [CrossRef] [PubMed]

56. Bidlingmaier, S.; Weiss, E.L.; Seidel, C.; Drubin, D.G.; Snyder, M. The Cbk1p pathway is important for polarized cell growth and cell separation in Saccharomyces cerevisiae. Mol. Cell. Biol. 2001, 21, 2449-2462. [CrossRef] [PubMed]

57. Voth, W.P.; Olsen, A.E.; Sbia, M.; Freedman, K.H.; Stillman, D.J. ACE2, CBK1, and BUD4 in budding and cell separation. Eukaryot Cell 2005, 4, 1018-1028. [CrossRef] [PubMed]

58. Versele, M.; Thevelein, J.M. Lre1 affects chitinase expression, trehalose accumulation and heat resistance through inhibition of the Cbk1 protein kinase in Saccharomyces cerevisiae. Mol. Microbiol. 2001, 41, 1311-1326. [CrossRef] [PubMed]

59. Weiss, E.L.; Kurischko, C.; Zhang, C.; Shokat, K.; Drubin, D.G.; Luca, F.C. The Saccharomyces cerevisiae Mob2p-Cbk1p kinase complex promotes polarized growth and acts with the mitotic exit network to facilitate daughter cell-specific localization of Ace2p transcription factor. J. Cell Biol. 2002, 158, 885-900. [CrossRef] [PubMed]

(C) 2017 by the authors; licensee MDPI, Basel, Switzerland. This article is an open access article distributed under the terms and conditions of the Creative Commons Attribution (CC-BY) license (http://creativecommons.org/licenses/by/4.0/). 